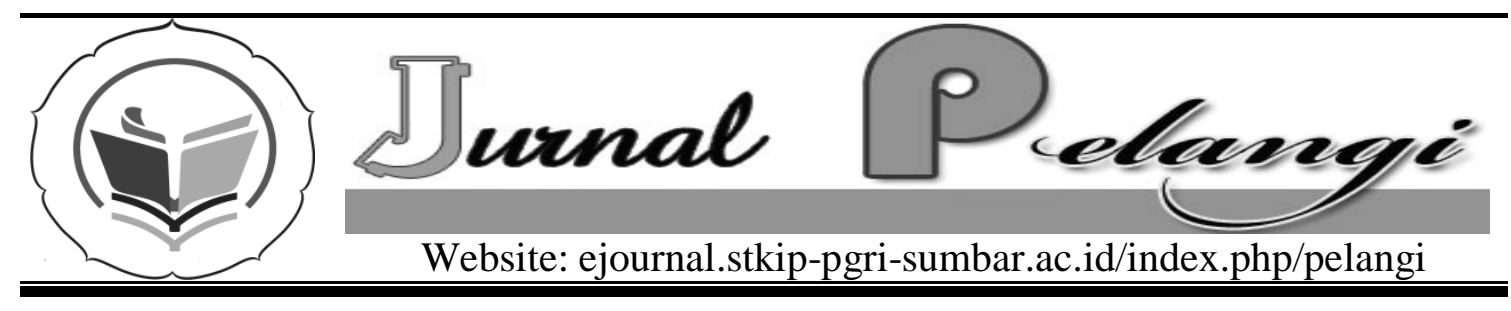

\title{
MAKNA TELEPON GENGGAM DI KALANGAN MAHASISWA STKIP PGRI SUMATERA BARAT
}

\author{
Slamet Rianto \\ STKIP PGRI Sumatera Barat
}

INFO ARTIKEL

Diterima:

Direview:

Disetujui:

Keyword:

Makna telepon

genggam di

kalangan mahasiswa

\section{Abstrak}

This research was aimed at identifying hand phone utilization by students at STKIP PGRI West Sumatera. This research was qualitative. The informant of this research were the students who had hand phone who were selected through snowball sampling technique. The data was collected through observation, interview, documentation, and the researcher himself as an active participant. The data was analyzed by using techniques as suggested by Miles and Huberman. The finding of this research showed that hand phone utilization by the students beside it was aimed at its function, as a tool for communication, but it is also to the owner prestige of him/her will be high. Hand phone symbolized one's success, modern, and high-tech minded. Hand phone had been a part of students life style today, because they wouldn't like being a part from old-fashioned class. By having hand phone, students had high self-confidence. Beside that, they will be welcomed to the group of those who had hand phone.

\section{PENDAHULUAN}

Perkembangan ilmu pengetahuan di Indonesia jauh tertinggal dibandingkan negara maju. Terlebih lagi dalam hal kemajuan teknologi. Era informasi yang berkembang sekarang ini telah mendorong negara maju dan negara berkembang terusmenerus melakukan penemuanpenemuan baru di bidang teknologi, termasuk teknologi informasi. Kemajuan teknologi komunikasi informasi di negara India dan Cina yang luar biasa terjadi karena sumber daya manusia yang mampu mengembangkan dan mengendalikan teknologi tersebut (Komputer Aktif,2002:76).

Perkembangan teknologi informatikan merupakan salah satu penggerak utama terjadinya transformasi budaya menuju budaya baru. Di Indonesia masuknya penetrasi teknologi informatika yang sangat gencar di semua aspek kehidupan mengakibatkan peningkatan pemakainya. Jumlah pelanggan internet mencapai 400 orang dengan jumlah pemakai sekitar 1 juta orang. Sementara itu, pemakai komputer berkisar 3-5 persen dari 220 juta penduduk. Jumlah televisi di atas 20 
juta orang (Parapak, 2000:266). Telepon genggam sebagai teknologi baru pemakainya telah mencapai 3 persen (Trend and Telecommunication, 2001:17). Apabila mengamati budaya teknologi, termasuk teknologi komunikasi informasi masyarakat Indonesia masih dalam taraf pemakai, penikmat, dan pembeli hasil-hasil teknologi. Indonesia jumlah pemakai barang dan jasa teknologi komunikasi dan informasi besar, tetapi Indonesia tidak memiliki produk unggulan apapun. Walaupun pasar yang ada di Indonesia sangat besar, tetapi ketiadaan tenaga ahli dibidang tersebut mengakibatkan pasar di Indonesia dibanjiri oleh produk- produk luar negeri.

Produk unggulan teknologi komunikasi informasi yang membanjiri pasaran di Indonesia saat ini adalah telepon genggam ( hand phone ) atau disingkat HP dan sering juga disebut telpon seluler ( ponsel ). Reklame produk ini setiap hari dimuat di surat kabar, majalah, televisi serta tayangan bioskop, baik yang dikemas sebagai iklan, hadiah, produk berhadiah, maupun sebagai alat kebutuhan seharihari. Pemakai produk ini menyebar pada semua tingkatan umur, jenis kelamin, pendidikan, dan pekerjaan. Mereka menggunakan alat itu dengan berbagai fungsi dan tujuan. Telepon genggam tidak hanya sebagai alat komunikasi, tetapi karena fasiltas yang dimilkinya, benda itu berfungsi sebagai penyimpan data, internet, perbankan, telivisi, game, camera, foto, radio, gambar, musik, pengiriman pesan pendek (Short Message Services atau SMS), dan lainlain.

$$
\text { Teknologi menyebabkan }
$$
perubahan makin cepat dan berskala besar di mana batas geografis, ras, agama, maupun budaya tidak lagi menjadi hambatan karena manusia dan teknologi yang dimiliki akan memudahkan semua kebutuhan hidupnya. Kehidupan masyarakat kota yang makin maju juga menghendaki pemenuhan kebutuhan akan sesuatu yang bersifat cepat, efesien, enak, nyaman, dan gaya. Jumlah pemakai telepon genggam terus meningkat sesuai dengan meningkatnya iklan yang merebak di masyarakat. Telepon genggam sebagai benda budaya telah berubah menjadi sebuah image budaya bagi pemakainya. Melalui iklan dan promosi besar-besaran, yang di dalamnya terdapat konsumsi tanda atau aspek simbolik, benda-benda menjadi sumber kepuasan utama yang diperoleh pemakainya. Oleh karena itu, sebetulnya selalu ada pesan atau tanda dari pemakai telepon genggam kepada orang lain tempat ia ingin menunjukkan sebuah gengsi atau status sosial tertentu dari pemakainya (Jacob, 2000:283).

Sementara itu, semua kebutuhan manusia terutama budaya materi, dalam budaya

massa akan ditempeli dengan merek dagang atau logo oleh produknya. Merek dagang dan logo merupakan kondensasi modal budaya sebagai properti citra ( Lury, 1998:156 ). Oleh karena itu, sangat mungkin untuk melihat kesinambungan dalam cara-cara bagaimana individu membuat pemaknaan sosial melalui pemanfaatan benda-benda materi dalam masyarakat ( Lury, 1998:20 ).

Di kalangan masyarakat sekarang ini, telepon genggam masih dianggap sebagai

teknologi terkini dibidang komunikasi. Benda kecil yang sangat praktis dibawa ini sangat diminati oleh masyarakat dari segala lapisan, jenis kelamin, maupun pekerjaan. Kaum muda dianggap sebagai pengguna terbesar telepon genggam. Teknologi 
informasi yang masuk ke Indonesia sekitar 10 tahun terakhir ini langsung mendapat tempat dihati masyarakat luas. Di Indonesia tercatat sekitar 7.3 juta pengguna telepon genggam dan 56 persen di antaranya adalah kelompok muda, di bawah umur 20 tahun (Kompas, 2000:40).

Telepon genggam pada saat sekarang merupakan salah satu kebutuhan primer masyarakat mulai dari kota sampai perkampungan. Telepon genggam bukan lagi barang mewah yang dimiliki oleh kelas tertentu, tetapi semua kalangan dari orang tua sampai anakanak. Telepon genggam bukan lagi barang mahal yang bisa dimiliki kalangan berduit, tetapi orang miskin sekalipun tidak ketinggalan memilikinya. Terima Bantuan Tunai (BLT) digunakan untuk beli telepon genggam. HP tidak saja kebutuhan kalangan pekerja "kerah putih" tapi juga tukang sayur, tukang becak, tukang ojek, pemulung sekalipun ada HP dalam sakunya.

Tingginya tingkat penggunaan HP pada setiap kalangan selain kebutuhan komunikasi juga trend. Sebagai manusia yang hidup di zaman modern sekarang ini merasa bangga dengan kemudahan teknologi dan komunikasi. Dunia tidak lagi dirasakan luas, tetapi kecil seperti dalam genggaman. Jarak tidak lagi jauh karena dipersingkat oleh signal. Menurut Anthony Giddens (2008:12), kemajuan IPTEK perlu juga diantisipasi karena di samping memberikan banyak manfaat bagi manusia, IPTEK juga berpotensi membawa dampak negatif bagi kehidupan manusia.

Pada satu sisi HP memberikan dampak yang amat positif bagi masyarakat karena memudahkan komunikasi. Pada sisi lain HP juga bisa memberikan dampak negatif, ketika penggunaannya tidak lagi pada hal yang subtansi. Menurut data dari penelitian
"Survei Siemens Mobile Phone" 58 persen orang Indonesia lebih suka memilih SMS dari pada membaca buku setiap hari (Nurudin,2005:191).

Lembaga kajian intelektual

Sumatera Barat Intellectual Society (SIS) pernah melakukan penelitian sederhana terhadap penggunaan teknologi di kalangan pelajar SLTA sederajat di Kota Padang pada bulan April 2008 yang lalu. Fakta yang pernah ditemukan dari 100 orang responden, 19 persen siswa meyimpan video dan gambar porno di HP-nya. Terkuaknya rekaman hubungan seksual sepasang remaja di Painan, hal ini membuktikan bahwa pengaruh perkembangan teknologi dapat merusak moral generasi muda.

Sehubungan dengan yang telah dipaparkan di atas, berdasarkan pengamatan penulis dalam kehidupan sehari-hari mahasiswa di kampus STKIP PGRI Sumatera Barat sekitar 95 persen di antaranya pengguna telepon genggam. Kepemilikan telepon genggam di kalangan mahasiswa tidak tergantung dengan ukuran pendapatan dan pekerjaan orang tuanya. Bagi mahasiswa yang penting punya telepon genggam, mereka rela menunda pembayaran uang kuliah, uang ujian, dan uang kost. Di samping itu mahasiswa seringkali menggunakan telepon genggam tidak mengenal tempat, waktu, dan suasana sepertinya tidak indah hidup tanpa HP. Bahkan, dering telepon genggam seringkali menjengkelkan, membuat serba salah, bahkan memalukan. Dering telepon genggam yang diubah dengan bermacam-macam lagu-lagu dan hal ini seringkali terdengar ditempat yang tidak pantas, misalanya di ruang kuliah, ruang seminar, ruang rapat, kantor dan tempat ibadah bahkan di jalan umum. Mahasiswa atau pemakai telepon genggam ini sering tidak mengindahkan 
etika dan norma cara pemakaiannya. Oleh karena itu, benda kecil ini bisa berubah menjadi wabah yang dapat menggangu privasi dan ketentraman.

\section{PEMBAHASAN}

A. Telepon Genggam sebagai Status
Kelas dan Gengsi
Pemakaian telepon genggam di kalangan mahasiswa STKIP PGRI sudah dianggap hal yang biasa. Hal ini disebabkan oleh jumlah pemakai alat ini makin meluas dan terus bertambah jumlahnya. Sementara itu, tingginya angka permintaan telah mendorong banyak produsen alat ini secara besarbesaran mengiklankan produknya sehingga sehingga harga yang dulunya mahal sekarang semakin terjangkau oleh mahasiswa. Selain itu, semakin banyaknya penyediaan jasa dapat juga mempengaruhi meningkatnya produksi. Persaingan yang semakin ketat antara para produsen menjadikan semakin banyaknya pilihan bagi mahasiswa. Benda teknologi canggih ini pun semakin banyak dijual dalam bentuk bekas pakai. Dengan cara ini harga yang tinggi bisa ditekan menjadi lebih rendah dan di kalangan mahasiswa yang mampu membeli semakin bertambah. Disisi lain daya beli mahasiswa khususnya yang mempunyai ekonomi orang tua kelas menengah keatas juga semakin tinggi sehingga merek dan jenis terbaru dari produk ini selalu diserbu oleh mahasiswa.

Telepon genggam selain menekankan pada aspek fungsinya juga gengsi menjadi pertimbangan bagi mahasiswa dalam kepemilikan barang tersebut. Hal ini tidak terlepas dari sifat yang biasanya selalu ingin berbeda mengikuti gengsi, sehingga telepon genggam pun akan diberi hiasan atau aksesoris. Hal ini sejalan dengan hasil observasi yang peneliti lakukan dengan
TK seorang mahasiswa program studi pendidikan bahasa Inggris yang berasal dari Solok. Pada HP yang ia gunakan selalu memakai hiasan atau asesoris yang menonjol menurut ia supaya kelihatan lebih bergensi, karena bentuk lebih menjadi pertimbangan pokok dari pada fungsi.

Bekaitan dengan status kelas dan gengsi dalam pemaknaan telepon genggam ini, diketahui

bahwa setiap orang tentu ingin dikatakan bergensi apabila memiliki telepon genggam

dengan fitur-fitur yang lengkap atau dengan memiliki model terbaru maka penampilan dan gengsinya sebagai seorang mahasiswa yang memiliki barang canggih nan kecil ini akan naik

Disamping itu sebenarnya kalau zaman sekarang tidak memiliki telepon genggam,

rasanya tidak cocok lagi. Dengan cara ini pemilik ingin, memperlihatkan siapa dirinya, status ekonomi atau kelasnya. Dengan memiliki telepon genggam dengan merek termahal dan seri terbaru, serta nada dering lagu tertentu mahasiswa ingin memperlihatkan kelas sosialnya karena biasanya merek, seri terbaru, maupun dering lagupun memiliki arti bahwa pemiliknya selalu ingin mengikuti mode dan ini memiliki konsekuensi pada biaya.

Dengan memiliki merek dan seri terbaru, orang lain akan menganggap bahwa

pemiliknya memiliki status sosial ekonomi tinggi serta gengsinya akan naik. Disamping telepon genggam dengan seri terbaru, status yang tinggi juga muncul pada pemilik telepon genggam dengan nomor-nomor favorit.

Nomor-nomor perdana itu umumnya diperjual belikan dengan harga yang tinggi sehingga tidak cukup anggaran seseorang tidak akan 
mampu memiliki nomor-nomor cantik tersebut. Selain itu, dering lagu yang ada pada telepon genggam bisa pula menunjukkan dari kelas seperti apa pemiliknya. Pilihan-pilihan lagu, termasuk memasukkan lagu-lagu baru, bisa dianggap mencerminkan selera pemilik tersebut dalam hal musik. Walaupun musik itu sifatnya universal. Dalam memilih dering lagu seperti klasik, jazz, pop, dan sejenisnya dianggap sebagai orang yang berasal dari kelas menengah. Sementara itu, yang memiliki dering lagu dangdut atau lokal, dianggap sebagai berasal dari kelas bawah.

Dering lagu ini sekaligus sering dipakai sebagai alat pembeda bagi pemilik telepon genggam terhadap panggilan seseorang. Bisa terjadi seseorang hanya memiliki sebuah telepon genggam tetapi di dalamnya terdapat beberapa dering lagu sekaligus sebagai pembeda panggilan dari pacar, orang tua, orang terdekat atau itu panggilan urusan bisnis dan pekerjaan. Namun tidak jarang bagi mahasiswa yang sangat sibuk dengan aktivitasnya, ia akan memilih dering lagu yang berbeda. Dengan cara ini, sipemilik akan sangat mudah mengidentifikasikan telepon genggam mana yang berdering, baik pada saat bersamaan maupun tidak bersama.

Berkaitan dengan makna yang ingin ditampilkan mahasiswa ada dua hal dalam pemilikan telepon genggam ini. Pertama, ada yang menganggap bahwa dengan memiliki telepon genggam maka pamor dan gengsinya sebagai orang yang memiliki barang canggih ini akan naik. Artinya, bahwa dengan memiliki telepon genggam sebenarnya ia sedang berkomunikasi lewat barang itu, ia ingin memperlihatkan miliknya pada orang lain, baik sema pemakai maupun orang lain yang tidak memiliki. Dengan cara ini pemilik ingin, memperlihatkan siapa dirinya, status ekonomi atau kelasnya. Kedua, dengan memiliki telepon genggam dengan merek termahal dan seri terbaru, serta dering lagu tertentu mahasiswa ingin memperlihatkan kelas sosialnya karena biasanya merek, seri terbaru, maupun dering lagu itu memiliki makna bahwa mahasiswa, selalu ingin mengikuti mode dan ini memiliki konsekuensi pada biaya. Merek mahal dan seri terbaru umumnya mempunyai harga yang masih tinggi karena fasilitas yang disediakan pada telepon genggam terbaru itu biasanya makin lengkap dan canggih. Dengan memiliki merek dan seri terbaru, mahasiswa lain akan menganggap bahwa pemiliknya memilki status sosial ekonomi tinggi serta gengsinya akan naik.

B. Telepon Genggam sebagai Lambang Kemajuan,Kemodernan dan Kesuksesan

Dalam masyarakat kota ukuran kemajuan, kemoderenan, dan kesuksesan seseorang sering diukur oleh kepemilikanya atas barang-barang yang bersifat material. Salah satunya adalah kepemilikan telepon genggam. Telepon genggam seakan-akan menjadi barometer kemajuan seseorang khususnya yang terkait dengan teknologi informatika. Di dalam pergaulan baik di saat berkenalan atau urusan pekerjaan lainnya, seseorang selain saling mengenal, baik lewat jabatan tangan atau memberikan kartu nama, hal yang selalu ditanyakan adalah nomor telepon genggamnya. Bahkan, banyak orang yang mencantumkan nomor telepon genggam pada kartu namanya

Perkembangan teknologi telepon genggam yang ada di pasaran akan mempengaruhi

mahasiswa untuk memilikinya. Apabila mahasiswa tidak memiliki telepon genggam, apalagi ia adalah 
mahasiswa yang pantas memilikinya, timbul kesan bahwa ia adalah mahasiswa yang kuno, ketinggalan zaman atau tidak bonafid. Cap-cap seperti inilah yang seringkali memaksa mahasiswa yang belum mampu memilikinya untuk tetap membelinya tanpa melihat fungsi dan anggaran pemeliharaannya.

Kepemilikan sebuah telepon genggam di kalangan mahasiswa seringkali dipakai

sebagai ukuran kesuksesan dalam hidup. Pemilik telepon genggam yang sudah bekerja akan membeli telepon genggam dengan uang sendiri. Mereka telah mampu membeli alat ini di pandang secara ekonomi termasuk orang yang sukses dalam bekerja. Artinya, dari penghasilan yang mereka terima, mereka mampu menyisihkan anggaran untuk membeli alat ini, termasuk pemeliharaannya karena ada kebiasaan pemilik telepon genggam untuk mengganti barang miliknya dengan seri, merek atau model yang lebih baru. Hal ini menuntut pembiayaan yang tidak sedikit. Hal yang sama berlaku bagi mahasiswa yang belum bekerja, yaitu bergantinya telepon genggam seseorang dengan seri yang lebih baru, hal ini menunjukkan bahwa orang tua atau keluarga pemilik telepon genggam itu termasuk keluarga berada.

Ukuran kesuksesan seseorang bagai mahasiswa seringkali dilihat dari jenis telepon genggam yang dimilikinya.

Ukuran kemajuan dan kesuksesan seseorang lewat kepemilikan telepon genggam ini, juga didasarkan anggapan mahasiswa bahwa untuk memilikinya membutuhkan modal ratusan hingga jutaan rupiah. Di samping itu, yang tidak kalah pentingnya adalah biaya operasionalnya, yaitu untuk membayar pulsa baik prabayar atau pascabayar. Pulsa tersebut harus dibayar dalam jumlah tertentu misalnya Rp 10.000 sampai Rp 100.000. Jumlah ini bagi mahasiswa yang tidak memiliki penghasilan merupakan jumlah yang cukup besar, sehingga seseorang yang memilki telepon genggam diartikan oleh mahasiswa sebagai orang yang cukup atau orang yang berasal dari keluarga mampu.

Makna telepon genggam bagi mahasiswa sebagai lambang kemajuan,kemodernan, dan kesuksesan. Fenomena di atas merupakan ciri dari masyarakat kota yang sangat terpengaruh budaya kapitalis, yang status sosial seseorang diukur bedasarkan kepemilikan atas benda-benda (materialisme). Lewat benda-benda itu lah mahasiswa ingin mendifinisikan siapa dirinya dan dari kelompok / kelas mana mereka berasal.

C. Telepon Genggam sebagai Mode, Tren dan Gaya Hidup

Begitu banyaknya tawaran bentuk telepon genggam oleh produsen, mahasiswa STKIP PGRI ini memaknainya sebagai mode, yaitu mode dalam menggunakan telepon genggam. Sebagai icon dari mode, maka telepon genggam yang mereka miliki merupakan lambang dari teknologi yang sedang trend. Bagi mahasiswa gaya dalam menggunakan teknologi yang canggih sangatlah mode baik itu bentuk, warna maupun asesoris dipertunjukkannya dalam menggunakan telepon genggam ini. Mode sangatlah mendukung dalam berpenampilan kalau memakai telepon genggam yang lagi trend akan menambah percaya diri.

Sebenarnya, dalam memilih mode yang trendi membutuhkan pengetahuan. Hal ini

diketahui dari hasil wawancara diperoleh informasi bahwa $\mathrm{Hp}$ yang trendi itu bukan hanya memakai $\mathrm{Hp}$ yang baru keluar di pasaran, yang harganya mahal. Tetapi lebih dari pada 
itu, diantaranya kemampuan dalam memberi asesoris dan yang membentuk $\mathrm{Hp}$ itu sedemikian rupa sehingga kelihatan menarik. Setiap orang tentu ingin dikatakan trendi dan gaul, siapa yang ingin dikatakan kuno, tidak gaul. Mode tidak harus baru, Hp yang ada bisa dimodivikasi atau diganti casingnya sehingga terlihat baru.

Tampil mode merupakan salah satu makna yang ditampilkan mahasiswa dalam

menggunakan teknologi telepon genggam di lingkungan kampus. Telepon genggam hanya sebagai gaya. Kalau dilihat dari sisi lain, mode, trend dan gaya hidup yang mereka maksud kadang-kadang terlihat tidak cocok sebagai seorang mahasiswa yang masih tergantung sama orang tuanya. Apalagi kalau dilihat sekarang dengan memiliki telepon genggam ini mahasiswa lebih cenderung menunda uang kost, uang kuliah, bahkan mereka rela mengurangi makan dan mengalihkannya untuk membeli pulsa.

Dengan adanya telepon genggam yang dimiliki mahasiswa ini seakanakan bagi

mereka ke kampus bukan hanya untuk menambah ilmu pengetahuan, tetapi juga ingin tampil trend dan gaya. Bila bisa tampil trend dan gaya merupakan salah satu kebanggan bagi mereka. Mahasiswa ingin tampil trendi dan gaya pada semua kesempatan dan tempat di kampus ini, apalagi bila tidak ada larangan atau teguran untuk menggunakannya.

Pencitraan telepon genggam sebagai mode, trend, dan gaya hidup ini dipicu oleh beberapa hal. Pemicu timbulnya makna telepon genggam sebagai mode,trend dan gaya hidup ini antara lain:

1. Semakin majunya perkembangan teknologi informasi
Perkembangan dunia informatika membawa pengaruh terhadap mode, telepon genggam, sehingga penampilan telepon genggam yang mereka pakai adalah pencitraan dari perkembangan teknologi itu sendiri. Perkembangan mode telepon genggam yang ada di media masa mempengaruhi mahasiswa untuk mengikutinya. Hal ini disebabkan, bagi mahasiawa yang memiliki Hp yang lagi trend sesuai dengan perkembangan teknologi sekarang akan menambah rasa percaya diri dan kekaguman orang.

Mahasiswa sangat rentan dengan perkembangan teknologi telepon gengam. Dalam keseharinnya selain membicarakan aktifitas perkuliahan, telepon genggam yang ia pakai merupakan bahan yang sering menjadi topik pembicaraan. Begitu berpengaruhnya mode yang ditampilkan sebuah telepon genggam. Hal ini terlihat dari hasil observasi yang peneliti lakukan di lapangan bahwa mahasiswa setiap sudut ruang dari tempat ketempat lain asik memainkan Hp, bahkan sewaktu dalam perkuliahan berlangsung. Mereka tidak menghiraukan waktu, tempat, untung dan ruginya.

Kalau dilihat, bahwa mode telepon genggam dari tahun-ketahun terus berkembang. Telepon genggam tidak lagi dipandang sebagai alat komunikasi tetapi lebih dari itu. Begitu banyaknya ragam dari mode telepon genggam yang dimiliki mahasiswa STKIP PGRI ini menunjukkan mereka tidak mau ketinggalan dari masalah mode atau trend dalam memaknai telepon genggam. Mode telepon genggam yang mereka peroleh dari tontonan atau gambargambar dari majalah selular Tren and Telecomunication.

Dengan perkembangan mode ini, terlihat mahasiswa yang dulunya hanya menggunakan telepon genggam untuk 
komunikasi sekarang sudah banyak perubahan. Mereka turut menunjukkan mode telepon genggam dalam kesehariannya.

2. Adaptasi dengan lingkungan dan ekspresi individu

Memasuki perguruan tinggi merupakan salah satu babak awal bagi mahasiswa untuk belajar mandiri. Hal ini disebabkan karena sebagian besar mahasiswa STKIP PGRI Sumatera Barat berasal dari luar kota Padang. Konsekuensinya banyak dari mereka yang tinggal di tempat kost yang jauh dari orang tua. Awal perkuliahan mereka menggunakan telepon genggam sebagai alat komunikasi. Seiring dengan itu juga mereka setiap hari di kampus menyasikan penggunaan telepon genggam para seniornya kapan saja dan di mana saja tanpa batas.

Lama kelamaan di dalam proses interakasi sosial sesama mahasiswa maka tontonan penggunaan telepon genggam yang diperagakan para senior terasa menarik untuk ditiru. Hal ini juga disebabkan karena biasanya pada kelompok-kelompok pertemanan, para anggota biasanya menyesuaikan visi, rasa kebersamaan termasuk dalam gaya menggunakan telepon genggam. Memiliki telepon genggam karena teman-temanya sudah memiliki, sehingga tergerak hatinya untuk memiliki. Sedangkan dilain pihak, mereka menggunakan telepon genggam karena melihat mode telepon genggam yang beragam dipakai orang atau teman sepermainannya.

Pengetahuan seseorang akan sesuatu akan mempengaruhi makna yang dicitrakan dalam kehidupannya. Makna telepon genggam bagi mereka adalah kerena pengetahuan dan interkasinya. Hal ini sejalan dengan hasil observasi bahwa tidak semua mahasiswa yang menggunakan telepon genggam itu memaknainya sama.
Ternyata, fenomena yang ditampilkan mahasiswa dalam menggunakan alat ini merupakan dampak dari adaptasi mereka bisa berubah, apakah perubahan itu kepada hal yang baik atau sebaliknya. Dapat ditarik kesimpulan bahwa makna telepon genggam bagi mahasiswa STKIP PGRI Sumatera Barat adalah sebagai mode dan gaya hidup. Hal ini dipicu oleh semakin maraknya mode-mode telepon genggam yang ditawarkan produksen. Disamping itu, ternyata makna ini didorong juga oleh hasil interaksinya dengan lingkungan.

Telepon genggam telah menjadi bagian gaya hidup dari mahasiswa masa kini. Mereka yang merasa tidak ingin dikatakan ketinggalan zaman akan berusaha untuk mendapatkan alat ini. Para pemakai telepon genggam, khususnya mahasiswa mengatakan bahwa mereka memakai telepon genggam kerena sedang ngetren di kalangan teman-temannya. Telepon genggam sudah menjadi gaya hidup mahasiswa. Sebagian dari gaya hidup dari masyarakat modern, gaya penampilan mahasiswa masa kini akan dilengkapi dengan perangkat telepon genggam ini.

Budaya konsumen yang berkembang di tingkat masyarakat perkotaan ini kemudian membentuk cap dan anggapan bahwa mereka tidak mampu membeli dan memiliki telepon genggam akan dianggap sebagai orang gaptek atau gagap teknologi. Cap ini di kalangan mahasiswa sangat kuat pengaruhnya karena mereka yang tidak memiliki telepon genggam pun akan dianggap sebagai "anak ngak gaul " (tidak mengikuti zaman). Anggapan seperti di atas telah memaksa kelompok mahasiswa untuk memiliki benda ini tanpa peduli bahwa mereka belum berpenghasilan. Akibatnya, justru akan menambah beban ekonomi orang tuanya. 
D. Telepon Genggam sebagai Citra bagi Pemakainya

Dalam masyarakat maju, budaya konsumen massal telah memaksa individu dan masyarakat untuk memperjelas diri dan orang lain dalam kaitanya dengan benda yang dimiliki. Banyak orang yang menggambarkan barang-barang yang dimiliki sebagai citra diri. Apabila orang itu kehilangan barang tersebut, akan mengalami siksaan pribadi atau penurunan harga diri. Mahasiswa dalam menggunakan telepon genggam adalah ingin tampil lebih gaya dan gaul. Ini juga didukung oleh hasil observasi, mahasiswa turut mempertunjukkan gaya melalui telepon genggam yang ia pakai.

Makna telepon genggam bagi mahasiswa di STKIP PGRI Sumatera Barat adalah sebagai hal yang dapat menambah rasa percaya diri. Dalam kaitanya dengan kepemilikan telepon genggam, para penggunanya juga merasakan bahwa dengan memilki barang itu mereka merasa bertambah rasa percaya dirinya dihadapan orang lain. Sebenarnya tanpa telepon genggam pun seseorang tetap bisa tampil percaya diri, tetapi kenyataannya tuntutan kehidupan masyarakat yang memaksa untuk memiliki barang itu mengingat ada simbol-simbol yang terkandung di dalamnya. Dengan telepon genggam, rasa percaya diri seseorang akan semakin meningkat karena di dalam telepon genggam itu telah terkandung simbol-simbol kesuksesan, gaya hidup, tingkat sosial ekonomi, dan sebagainya.

Di kalangan mahasiswa STKIP PGRI juga timbul pandangan bahwa seseorang akan merasa diterima dalam kelompoknya apabila mereka masingmasing memiliki gaya hidup yang sama, termasuk di dalam kepemilikan benda ini. Apabila seseorang belum bisa memilikinya, dianggap belumlah merupakan bagian dari kelompok itu. Bagi mahasiswa penampilan menjadi modal utama dalam bergaul tidak saja sesama jenis, tetapi juga dengan lawan jenis. Kaum muda yang merupakan pengguna terbesar alat ini umumnya memakai alat ini terutama dalam berhubungan dengan teman atau pacar. Telepon genggam ini menjadi vital mengingat pada masa pacaran ini dua individu saling mengenal satu sama lain lewat komunikasi, baik yang langsung maupun tidak langsung. Melalui telepon genggam ini pula mereka saling berkirim pesan dalam berkencan maupun aktivitas yang lain. Demikian juga dalam masa perkenalan awal antara dua orang, komunikasi lewat telepon genggam ini dianggap merupakan cara yang paling aman dan efektif karena kerahasiaanya sangat terjamin.

Jaminan kerahasian yang tinggi atas penggunaan alat telepon genggam inilah yang mendasari banyak pemakai untuk melakukan komunikasi atau mengirim pesan dengan orang lain, baik untuk pembicaraaan yang umum maupun masalah pribadi yang hanya diketahui oleh kedua belah pihak. Rupanya, pada zaman yang semakin maju ini, privasi atau kerahasian pribadi menjadi hal yang sangat dituntut oleh seseorang. Kebutuhan akan hal ini bisa dipenuhi oleh alat yang bernama telepon genggam.

\section{PENUTUP}

1. Makna telepon genggam bagi mahasiswa selain menekankan pada aspek fungsinya juga gengsi menjadi pertimbangan kepemilikan barang tersebut. Dengan memiliki telepon genggam maka pamor dan gengsinya sebagai mahasiswa akan naik. Artinya, bahwa dengan memiliki 
telepon genggam sebenarnya ia sedang berkomunikasi lewat barang itu, ia ingin memperlihatkan miliknya pada orang lain, baik sema pemakai maupun orang lain yang tidak memiliki.

2. Ukuran kemajuan, kemoderenan, dan kesuksesan seseorang sering diukur oleh kepemilikan atas barang-barang yang bersifat material. Salah satunya adalah kepemilikan telepon genggam. Makna telepon genggam bagi mahasiswa sebagai lambang kemajuan, kemodernan, dan kesuksesan. Hal merupakan ciri dari masyarakat kota yang sangat terpengaruh budaya kapitalis, yang status sosial orang diukur bedasarkan kepemilikan atas benda-benda (materialisme). Lewat benda ini lah mahasiswa ingin mendifinisikan siapa dirinya dan dari kelompok / kelas mana mereka berasal.

3. Telepon genggam telah menjadi bagian gaya hidup mahasiswa saat ini, karena mereka tidak ingin dikatakan ketinggalan zaman atau anak yang kurang gaul akan berusaha untuk menggunakan alat ini. Dengan adanya anggapan seperti diatas telah memaksa mahasiswa untuk memilki benda ini tanpa peduli bahwa mereka belum berpenghasilan. Akibatnya, justru akan menambah beban ekonomi orang tua.

4. Dengan kepemilikan telepon genggam, para mahasiswa merasa bertambah rasa percaya dirinya dihadapan orang lain. Di kalangan mahasiswa juga timbul pandangan bahwa seseorang akan merasa diterima dalam kelompoknya apabila mereka memiliki gaya hidup yang sama, termasuk didalam kepemilikan telepon genggam. Apabila seseorang belum bisa memilkinya, dianggap belumlah merupakan bagian dari kelompok itu. Bagi mahasiswa penampilan menjadi modal utama dalam bergaul tidak saja sesama jenis, tetapi juga dengan lawan jenisnya.

\section{DAFTAR PUSTAKA}

Bogdan, R. dan S.J Taylor, 1975. Introduction to Qualitative Methods. New York: John Wiley and Sons.

Barnard, Malcom. 2006. Fashion sebagai Komunikasi "Cara Mengkomunikasikan Identitas Sosial, Seksual, Kelas dan Benda". Alih bahasa: Idi Subandy Ibrahim. Bandung: Jala Sutra

Faisal, Sanafiah. 1990. Penelitian Kualitatif Dasar-Dasar dan Aplikasi. Malang : Pustaka Sinar Harapan.

Featherstone, M. 2001. Posmodernisme dan Budaya Konsumen (terjemahan). Yogyakarta: Pustaka Pelajar.

Guy Daniel,"Mobile Manoeuvres", Communications International, October 1997

Jacob,T. 2001. Tahun-Tahun Yang Sulit, Mari Mencintai Indonesia, Jakarta: Yayasan Obor.

Johnson,D.P. 1990. Teori Sosiologi Klasik dan Modern. Jakarta: Gramedia.

Kompas. 2002, “ MMS Teknologi Gaul Terkini”, 3 Agustus, hlm. 40. 2002,"Sony Ericsson Bertekat Rebut Kembali Pasdar Ponsel Indonesia“, 3 Agustus . hlm. 40.

$$
\begin{gathered}
\text { Komputer Aktif ,2002,"Ponsel } \\
\text { Anda,Pribadi } \\
\text { Anda“.No19.Januari.hlm. 56. } \\
\text {-------, 2002, “ Kehalian dan } \\
\text { Tukang ", No. 20. Januari, }
\end{gathered}
$$


hlm. 76. Koentjaraningrat. 1980. Sejarah Teori Antropologi. Jakarta: Universitas Indonesia. -1992. Beberapa Pokok Antropologi Sosial. Jakarta: Dian Rakyat 1996. Pengantar Antropologi I. Jakarta: Rineka Cipta. -1997. Pengantar Antropologi ( pokok-pokok etnografi II). Jakarta : Rineka Cipta.

Lury.C. 1998. Budaya Konsumen, Jakarta: Yayasan Obor. M.Poloma,Margaret (1999). Sosiologi Kontemporer. Jakarta: Depdikbud. Moleong,J.Lexy.2000.Metodo logi penelitian Kualitatif.Bandung: Remaja

Muhadjir, Noeng. 1990. Metodologi penelitian Kualitatif. Yogyakarta : Rake Sarasin

Miles \& Huberman. Tanpa tahun. Analisis data kualitatif. Terjemahan oleh TjetjepRohendi Rosidi. 1982. Jakarta : Universitas Indonesia Press.

Muh.Muslih.2007.“Telepon Genggam Membantu atau Menggangu Siswa“"Diambil dari situs http://www.jiptumm.org.artike 1.html.Tanggal 25 Januari 2007.

Parapak,J. 2000.“ Maraknya E .Commerce ",Dalam Ninok Laksono, Indonesia abad XXI di Tengah Kepungan Perubahn Gobal.Jakatarta: Kompas Media Nusantara. hlm. 259 -269.

Queeny (2007)“Arti dan makna (fungsi) telepon genggam (handphone)“ Diambil dari situs http://www.jiptumm.org.artike
1.html.Tanggal 23 Februari 2007.

Riztzer,G. 1992, Sosiologi Ilmu Pengetahuan Berpradigma Ganda, Jakarta:Rajawali Pers.

Salim, A. 2002. Perubahan Sosial, Sketsa Teori dan Refleksi Metodologi, Kasus Indonesia. Yogyakarta: Tiara Wacana.

Spradley, JP. 1980. Metode Etnografi. Yogyakarta: Tiara Wacana. Sunarto,Kamanto.2000.Penga ntar Sosiologi. Jakarta : Fakultas Ekonomi Universitas Indonesia.

Seidman, I.E. 1991. Interviewing as Qualitative Research: A. Guide for Researchs in Education and the Social Sciences New York: Teacher College Press.

Soeprapto,Riyadi 2001. Interaksionisme Simbolik Perspektif Sosiologi Modern. Yogyakarta: Averroes Press dan Pustaka Pelajar.

Selular, 2001. " Yang Suka Gonta Ganti Ponsel”, No.12 Maret. hlm.18.

--------,2001.“Tujuh Larangan

Berponsel Saat

Nyetir",No.16.Juli.hlm14.

--------, 2001. " Horor di balik ponsel ", No.16. Juli .hlm. 20-21

Sugiono. 1995. Memahami Penelitian Kualitatif. Bandung: CV. Alfabeta. Soerjono,Soekanto. 1990. Sosiologi Suatu Pengantar. Jakarta : Rajawali Press. Triratnawati, Atik 2003. " Aspek Simbolisme Telepon Genggam " Artikel di Jurnal Humaniora Volume XV, No. $1 / 2003$.

Tilley,C. 2001."Etnography and Material Culture " dalam Atkinson. Et.al. (eds.) 
Handbook of Etnography.

London: Sage Publication.

Tren and Telecomunication, 2001. "Ponsel Bikin Sakaw", No. 02/1,Desember, hlm.8.

--------, 2001. “ Sst ... Ini Serius “, No.01/1 November.hlm. 8-9.

----------, 2001. “ Anda Termasuk Yang Mana", No. 01/1 November. hlm. 11.

2001."Bisnis Lewat SMS “,No.01/1.November, hlm. 17.

Wuradji. 1988. Sosiologi Pendidikan sebuah Pendekatan Sosiologi Antropologi. Jakarta: Dirjen Dikti. 